\author{
Bartłomiej Gapiński \\ (D) https://orcid.org/0000-0002-7285-0480 \\ Uniwersytet Jagielloński w Krakowie
}

\title{
Solidarność i wspólnota we wspomnieniach biskupa Józefa Zawitkowskiego. Spojrzenie historyczno-antropologiczne na społeczność wiejską Żdżar na Mazowszu
}

(li) https://doi.org/10.15633/9788374389952.09

W rozeznawaniu kultury ludowej ważne są źródła pozostawione przez tzw. świadków kompetentnych ${ }^{1}$. Taką osobą niewątpliwie był biskup łowicki senior Józef Zawitkowski (1938-2020). Biskup urodził się w Wale, należał do parafii św. Mikołaja w Żdżarach na Mazowszu i jej mentalność utrwalił. Przez lata był biskupem pomocniczym diecezji łowickiej, przewodniczącym Podkomisji Episkopatu Polski do spraw Muzyki Kościelnej, znany jest jako poeta o pseudonimie „ks. Tymoteusz”. Pozostawił on bogate świadectwo życia codziennego i świątecznego ze swoich rodzinnych stron, a mianowicie mazowieckiej wsi, przy czym szczególnie eksponował wartości wspólnotowe tej społeczności, relacje i solidaryzm. Przyszły biskup mieszkał w Wale, ale identyfikował się ze wspólnotą parafialną kościoła w Żdżarach. W adresowanym do mnie liście, który będzie przedmiotem tego wystąpienia, napisał: „Pochodzę ze Żdżar”. Świadectwo to znakomicie pokazuje, jak wyglądały typowe więzi społeczne oparte o solidarność mechaniczną, jak wspólnota wiejska reagowała na konfrontację z komunizmem w pierwszych latach Polski Ludowej. Prezentuję tutaj wspomnienia, które biskup Zawitkowski zawarł w swoim liście.

Korespondencja z biskupem Zawitkowskim była jednym z bardziej ożywczych poznawczo doświadczeń w moim życiu. Pracowałem wówczas nad dysertacją doktorską o starości wiejskiej (a konkretnie chłopskiej, czasów

1 M. Kula, Nie catkiem stare dzieje starości, „Historyka. Studia Metodologiczne” 44 (2014), s. 129. 
przełomu XIX i XX wieku oraz międzywojnia), która później ukazała się w postaci książki². Kiedy poprosiłem biskupa, by scharakteryzował mi świat wiejski ze swojego dzieciństwa, ten wkrótce przysłał mi list liczący 14 stron formatu A4, pisany wierszem. Działo się to wszystko latem 2011 roku. Odpowiadając na moją prośbę, hierarcha pisał:

Ośmielam się przesłać Panu kilka wspomnień z dzieciństwa. Może się przydadzą do Pańskich Opracowań naukowych ${ }^{3}$.

I faktycznie do tego listu wielokrotnie nawiązywałem, ale teraz mam szansę na prezentację artykułu bezpośrednio i wyłącznie opartego na tym źródle. Rok temu (jesienią 2020 roku) biskup zmarł. Myślę, że warto pochylić się i zastanowić nad światem chłopskim opisywanym przez tego duchownego. To wartościowe świadectwo.

\section{Wspólnota}

Wspólnota wiejska określała życie. Wpisywała się w ramy solidarności mechanicznej. Pisał o niej Émile Durkheim:

Istnieje solidarność społeczna, wywodząca się stąd, że pewne stany świadomości są wspólne wszystkim członkom danego społeczeństwa. To ją właśnie wyraża materialne prawo represyjne, przynajmniej w tym co dla niej zasadnicze ${ }^{4}$.

Istotnie społeczność wiejska, o jakiej tu mowa, kontrolowała życie zbiorowe i jednostkowe. Biskup Zawitkowski, opisując życie we wsi Żdżary, ukazuje świat wspólnych wartości, które integrowały. Ludzie byli do siebie podobni, jednorodni, odgrywający niezróżnicowane role społeczne. Hierarcha koncentruje się na podzielanych wartościach, uniformizującym jednostkowe życie światopoglądzie. Ciekawe jest to, że system kar za odstępstwa pojawia się w tle, nie jest pierwszoplanowy (a w postawie zasadniczej typowej dla tradycyjnej wsi istniał swoisty rygoryzm łączony z intensyfikacją karania) ${ }^{5}$. Nie

\footnotetext{
2 B. Gapiński, Ludzie starzy na wsi polskiej od schytku XIX wieku po rok 1939, Poznań 2014.

3 List biskupa Józefa Zawitkowskiego do B. Gapińskiego. Wspomnienia z dzieciństwa, 2011.

4 E. Durkheim, O podziale pracy spotecznej, przeł. K. Wakar, w: Klasyczne teorie socjologiczne. Wybór tekstów, red. P. Śpiewak, Warszawa 2008, s. 191.

5 C. Robotycki, Tradycja i obyczaj w środowisku wiejskim. Studium etnologiczne wsi Jurgów na Spi$s z u$, Wrocław 1980, s. 88.
} 
ma na przykład wzmianki o tak zwanych „odmieńcach”, wiadomo z innych źródeł, że na wsi tradycyjnej nie tolerowano osób samotnych (niezamężnych i bezżennych), uprzykrzając im życie ${ }^{6}$. Na takie ukazanie życia wiejskiego poniekąd odległego od rzeczywistości - niewątpliwie ma wpływ narracja biskupa: on wiejską wspólnotę idealizuje. Wspomnienia odnosi do dzieciństwa i młodości, kiedy pełen nadziei wchodził w życie. To żadna nowość. „Kraj lat dziecinnych" - jak wiadomo - pozostaje czasoprzestrzenią, o której mówi się na ogół dobrze. Świat biskupa wpisuje się w dychotomię zaprezentowaną przed laty przez Ludwika Stommę. W ujęciu potocznym i naukowym mamy tutaj wyrazistą polaryzację:

- kultury nieelitarne (chłopskie, plemienne), oparte na ustnym przekazie tradycji, kierujące się zasadami, cechujące wysokim stopniem rozbudzenia izolacji świadomościowej, nastawione na wyrażanie, typu zamkniętego;

- kultury elitarne, oparte na przekazie pisanym, celowościowe, o niskim stopniu izolacji świadomościowej, rozumiejące siebie jako system regul, typu niezamkniętego?.

Ze wspomnień biskupa wyłania się świat bliższy pierwszej z zaproponowanych charakterystyk. Świat młodości biskupa Zawitkowskiego to modelowe wręcz środowisko partycypantów kultury ludowej. W świetle tym widać co prawda przejawy opisywanego przez Durkheima podziału pracy, ale profesjonalizacja życia wchodzi wolno, chłopi żyją w podobny sposób, wyznają jeden porządek wartości.

Nieco inaczej zachowują się nauczyciele (siostry zakonne i nauczycielka ucząca dzieci), ksiądz, pobliscy zakonnicy kapucyńscy z Nowego Miasta nad Pilicą (do których chłopi jeżdżą się spowiadać i którym jako relikt feudalny składają grzecznościowo w ramach ofiary pierwociny płodów). Inni są wreszcie reprezentujący już radykalnie odmienny porządek, narzuceni z zewnątrz i przyjmowani niechętnie komuniści (choć i oni wpisali się w zadawnione wyobrażenia i struktury feudalne ${ }^{8}$ ). Ogólnie rzecz ujmując, wiejskie elity poza komunistami (nauczyciele, duchowni) i lud funkcjonują w symbiozie, nakłada się tutaj dychotomia przedwojenna chłopi-panowie (ale nie w takim

6 B. Gapiński, Ludzie samotni na wsi tradycyjnej, w: Społeczeństwo i media - analizy wybranych zagadnień, red. A. Surma, M. Śliwa, Lublin 2020, s. 74-82; B. Gapiński, O wspólnocie i samotnościach w kulturze ludowej, Gniezno 2021.

7 L. Stomma, Antropologia kultury wsi polskiej XIX w., Warszawa 1986, s. 145-146.

8 A. Leszczyński, Ludowa historia Polski. Historia wyzysku i oporu. Mitologia panowania, Warszawa 2020 , s. 495. 
wymiarze antagonistycznym, jaki przebija z pamiętników wydanych przed wojną przez Józefa Chałasińskiego ${ }^{9}$ ). Zresztą o dziedzicu zmuszonym do opuszczenia pobliskiego majątku - „panu Łockowskim” - ludzie ze społeczności wiejskiej wypowiadają się dobrze (miejscowa orkiestra chłopska - która przed wojną była przy dworze, a jej orkiestranci zwolnieni byli podczas prób od prac polowych w majątku - teraz działa przy straży pożarnej i udziela się głównie podczas uroczystości religijnych).

Światem wiejskim rządził, jak podkreśla biskup, kalendarz świąt maryjnych ${ }^{10}$. Maryja była blisko codziennych spraw chłopskich, wpisywała się w rym prac polowych, obowiązków gospodarczych, praktyk społecznych. Przez pryzmat wiejskich relacji społecznych tłumaczono sobie porządek transcendentny na sposób socjomorficzny ${ }^{11}$. Biskup bardzo często podkreśla też doniosłą rolę, jaką w wiejskim świecie odgrywała kobieta od obowiązków gospodyni, osoby wypiekającej chleb, wychowującej dzieci, wspomagającej męża, przędącej, do integrującej się w życiu zabawowym i poważnym $\mathrm{z}$ innymi kobietami. Jak wiemy $\mathrm{z}$ innych źródeł, socjalizacja religijna była $\mathrm{w}$ rękach przede wszystkim kobiet ${ }^{12}$. Stąd u biskupa ckliwe doświadczenie matki, babci, „ciotki Weronki”. Kobiety doradzają mężom, bawią się, czytają, uczestniczą w misterium powstawania chleba, czyli mają wyrazistą podmiotowość w życiu rodzinnym i społecznym. Realizują się przede wszystkim w rodzinie jako matki (było to wpisanie się w typowy dla kultury ludowej wzorzec kobiecości) ${ }^{13}$. Rytm życia kobiet wiejskich, co wiadomo z badań prowadzonych w okresie Polski Ludowej, wyznaczała praca, statystycznie pracowały one 18 godzin i 20 minut (44\% tego czasu przeznaczając na gospodarstwo domowe, $33 \%$ na prace polowe, a tylko 2\% na sprawy osobiste). Stąd, jak podaje Małgorzata Fidelis, mężczyźni zwykli mawiać: „Żeby mi kazano zastąpić żonę tylko na tydzień, to bym zwariowal"14.

9 J. Chałasiński, Młode pokolenie chłopów, t. I-IV, Warszawa 1938.

10 List biskupa Józefa Zawitkowskiego..., dz. cyt.

11 I. Bukraba-Rylska, Socjologia wsi polskiej, Warszawa 2008, s. 512.

12 T. Smolińska, Wspótczesna rodzina nosicielem tradycyjnego folkloru religijnego, w: Folklor - Sacrum - Religia, red. J. Bartmiński i M. Jasińska-Wojtkowska, Lublin 1995, s. 254, B. Kaliski, Archidiecezja gnieźnieńska w czasach komunizmu 1945-1980, Gniezno 2012, s. 291.

13 I. Kuźma, Wspótczesna religijność kobiet. Antropologia doświadczenia, Wrocław 20o8, s. 154.

14 M. Fidelis, Równouprawnienie czy konserwatywna nowoczesność? Kobiety pracujace, w: K. Stańczak-Wiślicz, P. Perkowski, M. Fidelis, B. Klich-Kluczewska, Kobiety w Polsce 1945-1989. Nowoczesność, równouprawnienie, komunizm, Kraków 2020, s. 150. 
Jeśli chodzi o autorytety wiejskie - niewątpliwie respekt, co podkreślał biskup, posiadali ludzie starzy (łączeni z życiem religijnym) ${ }^{15}$. Odgrywali oni wyrazistą rolę w sferze publicznej, byli - jak podaje Urszula Lehr - „kustoszami pamięci” i „celebransami obrzędów”"16. Dla dzieci ważni byli rodzice: $w$ rodzinie szanowało się i całowało przed pójściem spać ojca i matkę w rękę. Ceniono osoby służące przy kościele i wyróżniające się w praktykach religijnych (np. „pannę od obrazu”, „chłopaka od chorągwi”). Szanowano miejscowych strażaków, wyróżniających się także podczas czynności religijnych. Dziadek biskupa - ochotniczy strażak, „dziadziuś Franciszek” - na łożu śmierci powie, że po śmierci chce, by w następujący sposób wyglądała jego droga pogrzebowa:

Do kościoła zawieźcie mnie na strażackim rekwizycie. Mundur strażacki zachowaj dla siebie i pilnuj straży. Do grobu niech mnie zaniosą strażaki ${ }^{17}$.

Wspólnota wiejska określała życie, towarzyszyła ludziom tak podczas święta, jak w życiu codziennym, podczas zabawy i smutku, w zdrowiu i chorobie (a nawet w śmierci, bo umierano w obecności kręgu wiejskiego). Zmorzenie chorobą stanowiło sytuację, kiedy proszono duchownego, by przyjechał do osoby cierpiącej, przychodzili wówczas też sąsiedzi, gromadziła się społeczność wiejska. Biskup opisuje, że podczas ciężkiej choroby przy cierpiącym gromadziła się cała wspólnota wiejska:

Przyjazd księdza do chorego był przeżyciem całej wsi. Przychodziły kobiety ze wsi, ze świecami. Gdy ksiądz przyjechał, śpiewały: „Niechaj będzie pochwalony Przenajświętszy Sakrament”. W izbie, gdzie był chory, był stół przykryty białym obrusem, stał krzyż i zapalone świece. Jak w kościele na ołtarzu, tam ksiądz zostawił Komunię świętą, potem rozmawiał z chorym, spowiadał go. Ludzie wychodzili do drugiej izby, albo na zewnątrz domu, i śpiewali: „U drzwi twoich stoję, Panie”. Ksiądz namaszczał chorego i stąd utarła się nazwa - ostatnie namaszczenia. Na Komunię mogli już wejść wszyscy. Ksiądz udzielał choremu Komunii świętej, błogosławił choremu i zebranym. Niektórzy podchodzili do chorego, całowali go w rękę - jakby na pożegnanie ${ }^{18}$.

15 S. Czarnowski, Kultura religijna wiejskiego ludu polskiego, w: S. Czarnowski, Dzieła, t. 1, Warszawa 1956, s. 105-106.

16 U. Lehr, Kulturowe paradygmaty starości w społeczności lokalnej. Tradycja i wspótczesność, w: Ludzie starzy i starość na ziemiach polskich od XVIII do XXI wieku (na tle porównawczym), t. 2: Aspekty spoteczno-kulturowe, red. A. Janiak-Jasińska, K. Sierakowska, A. Szwarc, Warszawa 2016, s. 425.

17 List biskupa Józefa Zawitkowskiego..., dz. cyt.

18 List biskupa Józefa Zawitkowskiego..., dz. cyt. 
Wspólnota towarzyszyła też rodzinie podczas czynności pogrzebowych i tuż po śmierci, kiedy zmarły spoczywał na katafalku. Adorowano jego ciało, modlono się, żegnano.

W wieczór przed pogrzebem do domu zmarłego przychodziła cała wieś na różaniec. Modlili się, potem wspominali, opowiadali o zmarłym ${ }^{19}$.

Sam pogrzeb był również manifestacją wspólnotowości i solidarności grupowej, rozbudowane były procedury pożegnania (wyróżniał się specjalny „śpiewok”). Na tyle, na ile to możliwe, mieszkańcy wsi - głównie z kręgu rodzinno-sąsiedzkiego - uczestniczyli też w uczcie pogrzebowej, czyli stypie. Oddajmy głos biskupowi:

Przy krzyżu wioskowym ktoś z gospodarzy żegnał zmarłego. Do dobrego zwyczaju należało, aby głośno płakać. Czasem ktoś z najbliższych wypłakiwał całe elegie o zmarłym: „a kto nas teraz wyżywi, a kto pole obrobi” itp.

Był też w parafii taki zawodowy śpiewak pogrzebowy. Wzruszające były te pieśni pogrzebowe, a w nich cała nauka o niebie, o czyśćcu i piekle. Obowiązkowo rodzina i sąsiedzi musieli przyjść na „stypę” tzn. na obiad pogrzebowy, a na obiedzie powinien być bigos, wędlina, gorzałka i placek ${ }^{20}$.

\section{Bieda}

Czasy wojenne i powojenne to okres biedy, głodu, chorób i umieralności w masowej skali. Do tego dochodziła przestępczość i grabieże, rozboje, samosądy i gwałty ${ }^{21}$. Szczególnie uciążliwe były kradzieże. Już w społeczeństwie tradycyjnym przełomu XIX i XX wieku, jak podawali ludoznawcy, istniało na nie przyzwolenie ${ }^{22}$. W magii ochronnej rejestrowano cały szereg procedur, jak ustrzec się od złodzieja ${ }^{23}$. A w okresie kryzysu powojennego zjawisko to się nasiliło. Opowiadał biskup:

19 List biskupa Józefa Zawitkowskiego..., dz. cyt.

20 List biskupa Józefa Zawitkowskiego..., dz. cyt.

21 M. Zaremba, Wielka trwoga: Polska 1944-47. Ludowa reakcja na kryzys, Kraków 2012.

22 S. Udziela, Religia i modlitwa u ludu ropczyckiego, „Wisła” 3 (1889), s. 592.

23 C. Robotycki, Moja etnografia - spojrzenie zoddali, „Konteksty” 68 (2014) nr 1, s. 244. 
Bieda jest matką złodziei. [...] tworzyły się szajki złodziei, często uzbrojonych i okradali chłopów. Kradli świnie, krowy, konie, wozy. To była plaga. Starsi uradzili - trzeba wprowadzić stróża. Będzie chodzić w nocy dwóch ze stróżom, to takie duże kije i gdy pojawi się ktoś obcy to dzwonić i się bronić. Były samosądy, a antagonizm między niektórymi wioskami w pamięci żyje do dziśs ${ }^{24}$.

W wiejskim świecie czasów powojennych i w okresie stalinowskim bieda dokuczała. Głód, szerzące się choroby, katastrofalna opieka medyczna, odwoływanie się do wypróbowanych, ale już archaicznych procedur magicznych powodowało masową śmiertelność. Jak zauważa Philippe Ariès ${ }^{25}$, śmierć wiejska była „oswojona” - bliska, doznawana we wspólnocie, troskliwości, ludzie byli z nią spoufaleni (szykowali się na nią jak do podróży czy na odpoczynek po pracy). Jednak w słowach biskupa przebija tragiczny odcień śmierci:

Ludzie na wsi oswojeni byli ze śmiercią, bo śmiertelność była duża. Umierały dzieci, umierali ludzie młodzi, w sile wieku i starsi. Rozpoznawalność chorób była żadna, a pomoc medyczna rzadka. Ludzie umierali na duszności, na suchoty, na kolkę, albo na paraliż. Ludzie starsi oczekiwali na śmierć. Wprawdzie rodzice mieli zapewnioną tzw. ordynarię - materialną pomoc, ale los starszych był ciężki. Stąd częste u nas zdanie: „Żeby mnie już Pan Bóg zabrał do siebie"26.

Jak widać z powyższych słów, śmierć nie była szczególnie smutnej natury u ludzi starych, wręcz dla nich zgon był wybawieniem (to charakterystyczne dla religijności wiejskiej - szukanie ratunku w porządku transcendentnym w obliczu ziemskiej znikomości, cierpienia). To kolejne dezawuowanie „złotego wieku starości” (,golden age” of old age) ${ }^{27}$, który poczytywać należy jako potoczną, popularną, literacką, a niekiedy i naukową fikcję.

Wracając do tematu biedy, rodzi się pytanie, na ile wybór drogi kapłańskiej był przez biskupa podyktowany ubóstwem materialnym, wszechobecną biedą panującą w świecie Wału czy Żdżar. Czy poprzez wybór kapłaństwa chciał uniknąć nędzy, jaką obserwował wokół, czy groźna była dlań

24 List biskupa Józefa Zawitkowskiego... dz. cyt.

25 P. Ariès, Rozważania o historii śmierci, przeł. K. Marczewska, Warszawa 2007, s. 23-43.

26 List biskupa Józefa Zawitkowskiego..., dz. cyt.

27 P. Johnson, Historical reading of old age and ageing, w: Old age from antiquity to post-modernity, red. P. Thane i P. Thane, London, New York 1998, s. 1. 
ekonomia wiejska, rygor pracy rujnujący zdrowie? Pewną odpowiedź daje zwierzenie biskupa, utrzymane $\mathrm{w}$ formie spowiedzi, napisane pod koniec życia, a zawarte w jego biografii autorstwa Artura Żaka i Joanny Skrzypnik. Jako wikary biskup Zawitkowski trafił do Krośniewic w pierwszej połowie lat 6o. XX wieku. Wspominał później: „W Krośniewicach schlebiało mi, gdy mi ludzie mówili: jaki przystojny, jaki zdolny: gra, śpiewa, tańczy. [...] Kolacyjki, wódeczki, a krośniewiczanki kochliwe”28. Jednakże wieści o „księżowskiej kawalerce" doszły do ojca duchownego Bronisława Zawitkowskiego. Biskup mówi tutaj niezwykle szczerze i wprost: „Tata przyjechał, postawił na baczność i powiedział: «Jak masz być takim księdzem, to wracaj do domu: bierz się za robotę w polu». Pomogło!”29 Czyli jednak jakąś formą perswazji była groźba powrotu na wieś, do zwyczajnych obowiązków, rygoru pracy.

\section{Komunizm}

Nastaje jednak nowa epoka - przejęcie władzy przez komunistów, ostateczny kres świata ziemian, kontrowersyjna i budząca podziały reforma rolna. Szczególnie wrogo chłopi patrzyli na kolektywizację. Nie można było odmówić realizmu mieszkańcom wsi, co podkreśla Adam Leszczyński. Komuniści chcieli skłócić chłopów, lansując kolektywizację. Wedle słów Hilarego Minca usiłowali poróżnić trzy warstwy społeczne: „kułaków”, „średniaków” i „biedotę wiejską”. Przy czym cel ten się nie powiódł: „Była to - pisze Leszczyński - ideologiczna fantazja: chłopi zazwyczaj postrzegali spółdzielnię jako zamach na ich własność i występowali przeciwko tym planom niezwykle solidarnie"30. Opór chłopski podkreślają słowa biskupa Zawitkowskiego:

Chłopi bronili się przed kołchozami, które u nas nazywały się wspólnoty, później PGR-y, jeszcze później Kółka Rolnicze, ale wszystko zmierzało do kolektywizacji wsi ${ }^{31}$.

Reglamentowanie życia przez partię też chłopom się nie podobało. W zaistniałej sytuacji - w obliczu ucisku i prześladowań, a szczególnie wobec braków na rynku produktów rolnych - radzili sobie, funkcjonując w szarej

28 A. Żak, J. Skrzypnik, Życie w rytm Bożych nut. Opowieśćo biskupie Józefie Zawitkowskim, Kraków 2021, s. 225.

29 A. Żak, J. Skrzypnik, Życie w rytm Bożych nut..., dz. cyt.

30 A. Leszczyński, Ludowa historia..., dz. cyt., s. 504.

31 List biskupa Józefa Zawitkowskiego..., dz. cyt. 
strefie. Hierarcha zwraca uwagę na kreatywne obchodzenie ograniczeń, włącznie z jawnym łamaniem prawa, co jednak przybrało groteskową formę:

Przestępstwem w PRL-u był handel mięsem, bimbrem i jakąkolwiek żywnością. W mieście była bieda. Chłopi chcieli zarobić. Gdy było świniobicie, czuwał ktoś z chłopów i gdy jechał na rowerze milicjant, albo ktoś podejrzany, czujka gwizdał i czapkę miał daszkiem do tyłu. Milicjanci też tak szukali, żeby nie znaleźć, a najbezpieczniej było milicyjnym wozem odwieźć do miasta towar w umówiony punkt, a tam mieszczki sobie radziły. I tak się żywili pierwsi sekretarze i urzędnicy władzy ludowej ${ }^{32}$.

Ale system był też bezwzględny, bezlitośnie ściągając od mieszkańców wsi kontyngenty:

Najbardziej bolały chłopów obowiązkowe dostawy zboża, mięsa i to za marne grosze wg hektara. Najtrudniej było bogatym. Tych nazywano kułakami. Takim kułakiem był mój dziadziuś. Były ciężkie żniwa. Woziliśmy snopki, a na podwórku stał agent i krzyczał: Dlaczego jeszcze nie odstawione zboże dla państwa. Dziadek nie wytrzymał, chwycił za widły i po chłopsku chyba by załatwił agenta, ale ten uciekł. Za to kolegium przysądziło dziadkowi 3 dni aresztu - w żniwa ${ }^{33}$.

Tragedia rodziny, która została pozbawiona rąk do pracy podczas żniw, ukazuje specyfikę ordynarnych i bezwzględnych ingerencji komunistów w świat wiejski. Tymczasem chłopi postrzegali ziemię w sposób mistyczny. W innym fragmencie listu dziadek biskupa siejący zboże równolegle modli się, prosi matkę Ziemię, by wydała plon, wyżywiła rodzinę. Pobrzmiewają w tej mentalności wyobrażenia społeczności tradycyjnej, o których tak pisze Ewelina Szpak:

Ziemia [...] czuła, widziała i reagowała, podobnie jak ludzie rodziła, wymierzała sprawiedliwość. Jako tak pojęty i wymagający ciągłej pokory byt determinowała charakter pracy na niej, zmuszając do ciągłej gotowości, szacunku i poświęcenia ${ }^{34}$.

Tak dochodzimy do dalszej prawdy o wiejskim świecie. Nie poddaje się on komunistom, gdyż ludzie myślą podobnie, nie dają się dzielić i różnicować,

32 List biskupa Józefa Zawitkowskiego..., dz. cyt.

33 List biskupa Józefa Zawitkowskiego..., dz. cyt.

34 E. Szpak, Mentalność ludności wiejskiejw PRL. Studium zmian, Warszawa 2013, s. 111. 
żyją w przeświadczeniu, że uczestniczą w misterium przyrody. Religia przenika ich świat, a więzi solidarności mechanicznej dają poczucie jedności. Tu wspólnota daje poczucie zakorzenienia, ale także broni.

List biskupa pokazuje wiejskie życie jako wyidealizowane, ale kiedy się bliżej przyjrzymy temu historycznemu źródłu, dostrzeżemy detale i niuanse pozwalające zrozumieć dawną mentalność chłopską, którą na margines skierowała komunistyczna, ale też i kapitalistyczna historia. Tragiczne to, gdyż w świat wiejski współcześnie wchodzi próżnia, miejsce o takim potencjale społeczno-metafizycznym staje się przestrzenią „bez właściwości””35. Jednakże patrząc z perspektywy historycznej, należy mieć świadomość, że kultura powojenna wzniesiona została w oparciu o ,istotny udział komponentu wiejskiego", po brutalnej eliminacji warstw społecznych, takich jak ziemianie, burżuazja i drobnomieszczaństwo ${ }^{36}$. Świadectwo biskupa Zawitkowskiego pozwala uobecnić dawne tradycje i kontekst rodzenia się późniejszej rzeczywistości. Sympatia hierarchy jest oczywiście przy starym porządku, ale też kończąc swój list, nie ma on złudzeń, że wieś jego młodości „odeszła w siną dal".

Ideały wierne wspólnocie wiejskiej omawianego tutaj okresu podniesione zostały w innym kontekście. Już jako doświadczony duchowny ksiądz Zawitkowski będzie powołany przez prymasa Stefana Wyszyńskiego 19 września 1980 roku do kościelnej redakcji przygotowującej msze na falach Pierwszego Programu Polskiego Radia ${ }^{37}$. Rozpocznie wygłaszanie swoich sławnych kazań w kościele Świętego Krzyża w Warszawie. Oczywiście na tę decyzję komuniści zdecydowali się pod presją postulatów gdańskich, był to owoc zrywu znad wybrzeża i powstającej Pierwszej Solidarności. Aż do 1989 roku transmisje mszy stanowią jedyną audycję radiowa w polskich mediach, a biskup stanie się szczególnie tam popularny jako piewca tradycji wiejskich.

36 T. Kalniuk, Drogi i miejsca religijności ludowej. Antropologiczne studium nowych ośrodków kultu we wspótczesnej Polsce (Strachocina, Stryszawa, Sokótka i Legnica), Toruń 2019, s. 19.

37 A. Żak, J. Skrzypnik, Życie w rytm Bożych... dz. cyt., s. 266. 


\section{Abstrakt}

Solidarność i wspólnota we wspomnieniach biskupa Józefa Zawitkowskiego.

Spojrzenie historyczno-antropologiczne na społeczność wiejskq Żdżar na Mazowszu

Artykuł oparty jest o refleksję historyczną i etnologiczną. Pokazuje, jak wyglądało życie wspólnoty parafialnej w Żdżarach na Mazowszu. Źródłem historycznym jest tutaj wysłany dziesięć lat temu do autora list biskupa łowickiego Józefa Zawitkowskiego. Biskup pochodził z Wału, niewielkiej miejscowości położonej obok Żdżar, na Mazowszu. Opisał w swym liście życie tej wspólnoty chłopskiej. W pierwszej części artykułu ukazano, jak funkcjonowała owa wspólnota w oparciu o model solidarności mechanicznej. W części drugiej rozpatrzono położenie chłopów w obliczu biedy powojennej. W trzeciej pokazano, jaki stosunek miano wówczas na wsi do komunistów i jak starano się wykorzystywać przestrzenie manewrowania, aby pozwolić sobie na godziwe życie, wolność, swobodę, autentyzm. Artykułprzedstawia solidarność społeczności wiejskiej w obliczu przeciwności losu i represyjnego reżimu. Świat młodości biskupa Zawitkowskiego, który bezpowrotnie przeminął, stanie się, co wyeksponowano w zakończeniu artykułu, inspiracją do powstania cyklu kazań na falach Polskiego Radia z lat 8o. XX wieku, które będą emitowane jako pokłosie wcielenia w przestrzeń medialną postulatów gdańskich z I980 roku.

\section{Słowa kluczowe}

biskup Józef Zawitkowski, społeczność wiejska, czasy stalinizmu, życie codzienne wsi Żdżary na Mazowszu 
